DOI: 10.4312/an.54.1-2.87-98

\title{
Responses to Gone with the Wind among Slovenians on the Other Side of the Atlantic
}

\author{
Janko Trupej
}

\section{Abstract}

The article discusses the reception of the novel and the film Gone with the Wind in serial publications published by Slovenian immigrants in the United States of America. The analysis encompassed relevant articles that appeared in publications with different ideological orientations before the mid-1950s, i.e. until the onset of the modern African American civil rights movement. The reception by Slovenian Americans is compared with the contemporary general reception of the novel and the film in the United States. Taking the historical context into consideration, the article also endeavours to establish the reasons for the differences in the reception.

Keywords: Margaret Mitchell, Gone with the Wind, Slovenian Americans, serial publications, reception, American literature 


\section{INTRODUCTION}

In the 1930s, several writers from the former Confederate States of America published novels dealing with the Civil War-some of them tried to rehabilitate the image of the South (Gómez-Galisteo 15-16). Margaret Mitchell's 1936 bestseller Gone with the Wind, along with David O. Selznick's extremely successful 1939 Hollywood production of the same name, are examples par excellence of the latter endeavour. ${ }^{1}$ Gone with the Wind has had considerable influence on the general public's perception of the antebellum American South, the War Between the States and its aftermath (Gómez-Galisteo 60, 69-70, 177; Schuessler; Stewart). However, some aspects of the narrative that initially may not have been perceived as particularly problematic became an issue as audiences' 'horizon of expectations'2 about the portrayal of black people in fiction changed along with the gradual changes regarding the (un)acceptability of racism in society; for decades, Gone with the Wind has thus been challenged on the grounds of exhibiting racist attitudes towards African Americans, using racial slurs, perpetuating racial stereotypes, etc. (see, e.g., Asim 131-33; Gómez-Galisteo 7, 57-60, 177-78; Haskell 19-20, 32, 205-11; Ryan 22, 26, 48; Sova 167; Stewart). ${ }^{3}$ In spite of such criticisms, both the novel and the film have remained popular (Gómez-Galisteo 3, 101; Haskell 4-6; see also Wiley, "Epilogue" 424-26), although not as critically acclaimed as they once were (Gómez-Galisteo 176); however, habent sua fata libelli: in 2012, the Library of Congress (N. N.) included Gone with the Wind in an exhibition entitled Books That Shaped America.

The present article will analyse the reactions to Gone with the Wind (both the book and the film) in serial publications published by Slovenian immigrants in the USA before the mid-1950s. ${ }^{4}$ A study about the reception of Mark Twain's works among Slovenian Americans showed that the ideological orientation of

1 For instance, Jacqueline Stewart stated that the film "looks back nostalgically at idyllic days that are no more (because they never were)".

2 The Concise Oxford Dictionary of Literary Terms (Baldick 116) defines this concept-as used by Hans Robert Jauss — as "the set of cultural norms, assumptions, and criteria shaping the way in which readers understand and judge a literary work at a given time. It may be formed by such factors as the prevailing conventions and definitions of art (e.g. decorum), or current moral codes."

3 The controversy has intensified recently: in June 2020, amid Black Lives Matter protests, HBO removed Gone with the Wind from its streaming service, citing the film's 'racist depictions' as the reason. When it was made available again, the film was accompanied by two videos of scholars discussing its historical context (Stewart; see also Schuessler).

4 By the time Gone with the Wind again made major headlines upon the film being re-released for the centennial of the beginning of the Civil War in 1961, many Slovenian immigrant serial publications had ceased to exist. In addition, some are not available in the Digital Library of Slovenia, which was used to compile the corpus for the present analysis. 
a particular publication profoundly influenced the way the author was perceived (Trupej, "Ideological" 143-50), while a study about the Slovenian reception of selected novels including racist discourse established differences between the preand post-World War II responses to Gone with the Wind on the territory that now constitutes the Republic of Slovenia (Trupej, "Recepcija" 222-24). ${ }^{5}$ It can therefore be presumed that the discourse about Gone with the Wind in Slovenian American publications may also have been influenced by ideology.

To establish a frame of reference, an overview of the contemporary general reception of Gone with the Wind in the United States will be presented first. Afterwards, the responses to the novel and the film by Slovenians across the Atlantic will be analysed, and the possible reasons for the differences between the reception in different serial publications will be discussed.

\section{THE INITIAL RECEPTION OF GONE WITH THE WIND IN THE SOURCE CULTURE}

Gone with the Wind became an instant bestseller when it was published in 1936 and would eventually go on to sell more copies than any other literary work in the United States of America up to that point; it received numerous positive reviews (even garnering comparisons to classic works of world literature, including War and Peace and Vanity Fair), and was awarded both the Pulitzer Prize and the American Booksellers Association prize (Gómez-Galisteo 17-18; see also Haskell 22-23; Jeff; Schuessler; Wiley, "Prologue" XXII-III). ${ }^{6}$ However, critical opinions about the novel's artistic value were also expressed; ${ }^{7}$ an aspect of Mitchell's writing that was frequently criticized was her journalistic prose style or even lack of style (Gómez-Galisteo 25, 28; Haskell 23). Furthermore, some, for instance the scholar L. D. Reddick (qtd. in Gómez-Galisteo 22), warned that because of its immense popularity, this novel- "written with a passionate sectional and racial bias"-might influence the public's perception of the Civil War and the Reconstruction, while influential literary critic Malcolm Cowley (qtd. in Haskell 23) declared it "an encyclopaedia of the plantation legend". While communist and other left-wing reviewers offered particularly severe criticism of Mitchell's

5 The novel was translated into Slovenian twice: the first translation by Mirko Košir (under the pseudonym M. Rožič) was published in 1939/1940, and a retranslation by Janko Moder was published in 1965. After World War II, the film was also shown in Slovenian cinemas.

6 Gone with the Wind has sold more than 28 million copies worldwide (Haskell 6) and has been translated into over 30 languages (Gómez-Galisteo 22).

7 For instance, commenting on the novel, F. Scott Fitzgerald (one of the uncredited screenwriters for the film) stated that he "felt no contempt for it, but only a certain pity for those who consider it the supreme achievement of the human mind" (qtd. in Haskell 159). 
portrayal of slavery and racial relations, this issue was largely glossed over in the mainstream media at the time of the novel's initial publication (Gómez-Galisteo 57, 59), and Gone with the Wind was also referred to in positive terms upon the author's death in 1949 (see Wiley, "Epilogue" 423-24).

The writer herself rejected criticism of her portrayal of African Americans in Gone with the Wind, remarking that "most of the negro characters were people of worth, dignity and rectitude" (Mitchell 65). ${ }^{8}$ She later asserted that she never had the intention of 'insulting the Race'; quite the contrary, Mitchell claimed that her "relations [with African Americans] have always been those of affection and mutual respect" and that throughout her life, she often tried to help them in different ways. ${ }^{9}$ Furthermore, she stated that the African Americans she knew personally had expressed positive opinions about the book, and she speculated that Gone with the Wind was a pawn in the game of the radical left trying to incite Southern African Americans to join the Communist Party (Mitchell 223-24). She also expressed disapproval of the second incarnation of the Ku Klux Klan, while at the same time praising its predecessor:

The original Klan grew from a bitter necessity and Southern people respected it for they owed much to it. The present day Klan was a despicable organization and one abhorrent to all decent Southerners. In the early 1920s we suffered much from Klan activities here in Georgia. [...] I personally would feel very sorry if the moving picture version of "Gone With the Wind" helped even in a small way to bring it back to life. (Mitchell 119) ${ }^{10}$

Groups advocating for the rights of African Americans, for instance the National Association for the Advancement of Colored People (NAACP), raised objections against Gone with the Wind immediately after its publication (Jeff; Schuessler), and after the film was announced, they began to demand that certain racist elements of the novel be excluded. As a result, its racism was somewhat toned down; for instance, the slur 'nigger' is never used, and the Ku Klux Klan is completely absent from the movie (Asim 144-45; Gómez-Galisteo 59; Haskell 202-3; Jeff; Ryan 70-71; Schuessler; Stevens 367). Upon the film's release, some African Americans praised it for eliminating some of the racism (Jeff), while others

8 Gone with the Wind screenwriter Sidney Howard praised the characterization of African Americans, claiming they were "the best written darkies [...] in all literature" (qtd. in Mitchell 28).

9 For an overview of Mitchell's support of African American individuals and institutions, see Gómez-Galisteo (60). However, in her youth, she reportedly asked to be removed from a class which was also attended by a 'Negro' student (Haskell 200).

10 Through both parents, Mitchell descended from prominent Atlanta families, and thus had heard stories about 'Mr. Lincoln's War' and the 'Lost Cause of the Confederacy' from a very young age (Gómez-Galisteo 16, 23, 27; see also Haskell 106, 194; Wiley, “Prologue”XXI). 
condemned the film and picketed it (Haskell 214; Jeff; Ryan 71). ${ }^{11}$ Despite such controversy, it became one of the most successful motion pictures of all time and received ten Academy Awards, including Best Picture and Best Supporting Actress, which was awarded to Hattie McDaniel for her role as Mammy (Haskell 5, 31-32) - she was the first African American ever to get nominated (Jeff). However, even after she won an Oscar, she was criticized, for instance, by the president of the NAACP for portraying a stereotypical black character (Haskell 214).

\section{RESPONSES TO GONE WITH THE WIND IN SLOVENIAN AMERICAN SERIAL PUBLICATIONS}

Gone with the Wind was sporadically mentioned in the conservative newspaper Ameriška domovina. In 1937, it is referred to as an interesting and frequently discussed novel in one article, ${ }^{12}$ as a best-seller in another, ${ }^{13}$ while an article published the following year reports that a certain Slovenian American female claimed that she had read the novel in only two days and that one of her friends needed four days to finish it. ${ }^{14}$ In 1949, Ameriška domovina reported that sales of the novel had reached six million copies, which made it second only to the Bible in all-time sales figures..$^{15}$ When reporting on Mitchell's death, the newspaper erroneously stated that she wrote "one of the greatest films" 16 (she did not participate in writing the screenplay at all), and that she played the main role in it-Scarlett O'Hara was portrayed by Vivien Leigh. ${ }^{17}$

Several times the novel and/or film were mentioned in Catholic serial publications. In Glasilo K. S. K. jednote, Vital Vodušek mentions that Gone with the Wind is a best-seller, ${ }^{18}$ while someone writing under the name 'Father Kapistran' reports on the meticulous research that Mitchell supposedly conducted before she decided on the name 'Gerald O'Hara' for one of the important characters; she wanted to make sure that no one with this name lived in Savannah then or had lived

11 See Stevens (367-70) for a more detailed overview of the reactions to the film Gone with the Wind in African American serial publications.

12 N. N. Margaret Mitchell. Ameriška domovina, 25 May 1937, p. 3.

13 N. N. Rev. Vital Vodušek. Ameriška domovina, 9 October 1937, p. 4.

14 N. N. Eleanor Suhadolnik. Ameriška domovina, 31 March 1938, p. 6.

15 N. N. Gone with the Wind Hits 6 Million Sale [sic]. Ameriška domovina, 25 February 1949, p. 5.

16 Quotations not originally in English were translated by the author of the present article.

17 N. N. Margareth [sic] Mitchell umrla.Ameriška domovina, 17 August 1949, p. 1.

18 J. Z. Rev. Vital Vodušek, Missionary, Travels to aid Daraga Seminary. Glasilo K. S. K. jednote, 13 October 1937, pp.7-8. 
there in the past. ${ }^{19}$ The following year, Kapistran claims that the novel "is popular only by [sic] artificial advertising". ${ }^{20}$ Nova doba remarks that Gone with the Wind is both the longest and the most expensive film in history ${ }^{21}$ and later reports on its success at the Academy Awards. ${ }^{22}$ This newspaper also reports on the re-release of the film, stating that people cannot seem to get enough of it, since-according to a survey-30\% of those who already saw Gone with the Wind on the big screen during its original theatrical run, plan on seeing it at the cinema again. ${ }^{23}$ In Ave Maria, another Catholic newspaper, someone writing under the name 'Friar Fritz' expresses the following sceptical opinion about the novel: "Books of 'Mein Kamp' [sic] and 'Gone with the Wind' calibre are mere fleeting fads. Didn't the last mentioned certainly 'hit the breeze' awfully fast?" 24

Neither the novel nor the film received much attention from the editorship of the monthly magazine for Slovenian American youth titled Mladinski list. ${ }^{25}$ The only semi-noteworthy mentions of the novel come from letters sent to the magazine by its readers: John Poklar Jr. refers to it as a 'good book', ${ }^{26}$ while Jennie H. Padar states that what she remembered the most about Georgia's exhibit at the 1939 New York World's Fair were copies of Gone with the Wind in many different translations. ${ }^{27}$

Gone with the Wind was not prominently featured in Enakopravnost either; this liberal newspaper reports that when Kurt Schuschnigg-former Austrian chancellor of Carinthian-Slovenian descent ${ }^{28}$ - was held under house arrest by the Gestapo in 1939, he read Gone with the Wind; ${ }^{29}$ in an article a decade later, it is mentioned in passing that Mitchell is one of the authors who addressed issues concerning black people. ${ }^{30}$

19 Kapistran, Father. For God, home and country. Glasilo K. S. K. jednote, 29 March 1939, p. 8.

20 Kapistran, Father. For God, home and country. Glasilo K. S. K. jednote, 6 March 1940, p. 8.

21 N. N. Random Statistics. Nova doba, 7 February 1940, p. 6.

22 N. N. Najboljši film. Nova doba, 6 March 1940, p. 2.

23 Monitor, Fraternal. Take a Tip From "Gone with the Wind”. Nova doba, 26 November 1941, p. 7.

24 Fritz, Friar. Let's Review the Catholic's [sic]. Ave Maria, February 1942, pp. 38-39.

25 Mark Twain's work (especially his novel Adventures of Huckleberry Finn, which addresses the issue of slavery), was discussed a few times during the same period in Mladinski list; in some of the articles about Twain, socialist/communist sympathies were expressed (see Trupej, "Ideological" 148-49).

26 Poklar, John. His Hobby is Reading. Mladinski list, March 1939, vol. 18, nr. 3, p. 32.

27 Padar, Jennie H. The New York World's Fair. Mladinski list, October 1939, vol. 18, nr. 10, pp. 13-14.

28 The Slovenian version of his last name is 'Šušnik'.

29 N. N. Dr. Šušnik je žrtev nezaslišanega sadizma nacijskih [sic] gestapovcev. Enakopravnost, 17 November 1939 , p. 1.

30 N. N. Hrup julija meseca. Enakopravnost, 27 December 1949, p. 3. 
In Zarja, a magazine published by the Slovenian Women's Union of America, Gone with the Wind is described as an interesting novel that turned its author into a millionaire and earned her the Pulitzer Prize, ${ }^{31}$ while in a later article it is mentioned that the novel is set during and after the Civil War, and its protagonist Scarlett O'Hara is characterized as "selfish, wilful, magnetic and daring". ${ }^{32}$ Furthermore, Zarja reports that in the northern United States, there are calls to boycott the film because it allegedly misrepresented the Union Army's actions in the South; the article-which was published shortly after Nazi Germany invaded Poland-concludes that the value of the film is in showcasing the grim realities of war, which should make people strive for peace. ${ }^{33}$

A few noteworthy articles mentioning or discussing Gone with the Wind were published in the progressive newspaper Prosveta. Mary Jugg refers to it when discussing the status of women in the United States; she remarks that "[a]ccording to Margaret Mitchell's highly interesting and lengthy novel, 'Gone with the Wind', the status of American women since the Civil War period has changed in no small degree." ${ }^{34}$ Anna P. Krasna-a self-proclaimed reader of belles-lettres-reports that at the book fair in the Rockefeller Center in New York, Gone with the Wind was prominently displayed and received considerable attention. She states that she overheard a man declaring the following about the novel:

It is American, it does not propagate anything new, and it does not condemn anything old in the social sense. [...] The romance is presented in a romantic way, but at the same time in a way that makes it appear really modern. This appeals to our sophistical [sic] bourgeoisie, which took to the book like crazy. All our women who want to be perceived as cultured, modern and sophistical [sic] have Gone with the Wind in their hands while on the train, in a waiting room or when meeting somebody.

On the other hand, Krasna also reports on seeing a group of primary school children being led to the stand where Gone with the Wind was displayed, and one of their teachers heaping the highest praise upon the novel-even proclaiming it an 'unsurpassable historical study'. The author of the article rejects this notion and concurs with the former sceptical opinion; she goes on to criticize the American South because of its racism, lynchings, poor working conditions for labourers, etc. ${ }^{35}$ Even more severe criticism of the novel was expressed in the same newspaper by John Spelich:

31 N. N. Ali se je izplačalo spisati novelo "Gone with the Wind”? Zarja, June 1937, vol. 9, nr. 6, p. 168.

32 N. N. Gone with the Wind. Zarja, May 1937, vol. 9, nr. 5, p. 160.

33 N. N. Popis civilne vojne je povzročil ostro debato. Zarja, October 1939, vol. 11, nr. 10, p. 320.

34 Jugg, Mary. Women's Round Table. Prosveta, 14 October 1936, p. 8.

35 Krasna, Anna P. Književni semenj. Prosveta, 23 November 1936, p. 4. 
A young woman, Margaret Mitchell wrote a novel a few months ago. That, in itself, is no new thing. This book, "Gone with the Wind," marches on and on until it arrives at more than a thousand pages. It is just a good ordinary novel, a novel that one can take or leave alone. Like more than a million other folks, I tried to read "Gone with the Wind" and never get [sic] far enough to find out who it was that had gone with the wind nor where they went. I'll bet anything that ninety per cent of the folks who tried to read this best seller stopped on some pretext or other before getting halfway through. I know during my partial reading of the book, I was looking for a good excuse to lay the thing down. I'd leave it at a word even if the word had to do with sipping a glass o [sic] suds. But everyone said, "Oh, you must read Gone with the Wind," so I tried to. In my humble opinion, it is an excellent book-to block open the door so the cat can come in. Yet, in spite of my opinion, this novel has sold more than a million copies. The reasons are, we think, due to a rather extraordinary good press agent and the well-known sheep-like tendencies of the human race. Those are our sentiments and we will have to stand pat. ${ }^{36}$

However, not all the writing on Gone with the Wind published in Prosveta was as dismissive as the above examples; for instance, in 1940 it is simply reported that everybody is going to the cinema to see the film. ${ }^{37}$

Perhaps the most ideologically charged condemnation of the novel appeared in the socialist oriented newspaper Proletarec, where the author of the article states that, having read the book, he or she has no intention of going to see the film based on it, since it glorifies the aristocratic slave-holding society of the American South. In the continuation, the author quotes lengthy passages from an article ${ }^{38}$ by James Dugan, which begins as follows:

The issues of the Civil War were not solved by Appomattox; a decade of social struggle ensued in the South to decide whether the Negro was really to be free as an economic, political, and social man. It is the era of Reconstruction, 'The Tragic Era' of reactionary usage, which is most vilified in the literature of the Bourbons, now embalmed in the four hour film 'Gone with the Wind'. The picture brings up in typical distorted form the hated symbols of Reconstruction the carpetbagger, the Freedman's Bureau, the slogan 'Forty Acres and a Mule,' the increased taxes upon the landholders and the Union Army in occupation. The shocked bitterness of the slaveholders at finding themselves suddenly living in a democracy, and the forms of their counter-democratic action, such as the KKK, are idealized in 'Gone with the Wind'.

36 Spelich, John. Mohawks 573. Prosveta, 15 June 1938, p. 6.

37 Fifolt, J. F. Off the President's Bat. Prosveta, 14 February 1940, p. 7.

38 This article was originally published in the Marxist magazine Nerw Masses (Dugan 28-30). 
The ensuing passages of the article by Dugan condemn the film by referring to particular scenes as evidence for the above claims. ${ }^{39}$ However, not all the mentions of Gone with the Wind in Proletarec are ideologically charged. For instance, the newspaper reports that Vivien Leigh won the New York Film Critics Circle Award for Best Actress for her performance in Gone with the Wind. ${ }^{40}$ Furthermore, when discussing the contemporary economic system and the way it affects the working class, two articles in Proletarec state that some people do not want to acknowledge the reality of the situation, instead opting for the same modus operandi that Scarlett O'Hara had when she said: "I'll not think about that today; I'll think of it tomorrow." ${ }^{41}$ Towards the end of the 1940s, Raymond S. Hofses again expresses a more critical opinion, remarking that "[i]n reading such books as 'Gone with the Wind,' one gathers that slavery was altogether tolerable for those who lived in the upper strata of the slave class." ${ }^{2}$

\section{CONCLUSION}

Gone with the Wind was frequently mentioned/discussed in Slovenian American serial publications from 1936, when the novel was published, to 1940, i.e. the year after its big screen adaptation was released. In later years, Gone with the Wind was seldom mentioned, although a few noteworthy articles appeared in 1949-the year of Mitchell's untimely death.

The conservative newspaper Ameriška domovina reported on the great commercial success of Gone with the Wind, praised the narrative and voiced no critical opinions about it. The Catholic oriented newspapers Nova doba, Ave Maria and Glasilo K. S. $K$.jednote also focused on the novel's and film's commercial success, but the latter two publications expressed some doubts about Gone with the Wind's artistic value.

Gone with the Wind was mentioned only in passing in the youth magazine Mladinski list and the liberal newspaper Enakopraonost. It was discussed somewhat more at length in the women's magazine Zarja, but the articles about it do not have a clear ideological agenda.

The situation was markedly different in the progressive newspaper Prosveta and the socialist newspaper Proletarec, where-although not all mentions of the novel and/or film were ideologically charged-Gone with the Wind was severely criticized both for its alleged lack of artistic value and for clearly favouring the status quo ante bellum as far as social and especially racial relations are concerned.

39 J. D. "Gone with...” Proletarec, 14 February 1940, p. 6.

40 N. N. How Did Your Favorite "Star" Rank This Year? Proletarec, 15 January 1941, p. 6.

41 N. N. Labor, Capitalism And [sic] Socialism. Proletarec, 1 July 1942, p. 6; Hofses, Raymond S. Bluffing Is a Great Profession. Proletarec, 23 April 1947, p. 6.

42 Hofses, Raymond S. Reflections. Proletarec, 8 September 1948, p. 6. 
The lack of criticism of Gone with the Wind in most Slovenian American serial publications can perhaps be at least partially attributed to the fact that Slovenians only began to immigrate to the United States in large numbers after the Civil War and the Reconstruction had ended (Drnovšek 17), and thus had little to no personal involvement in the events from the period in which the narrative is set. Furthermore, Slovenian immigrants mainly settled in the Midwest and Northeast (Ohio, Pennsylvania, Illinois, Minnesota, etc.), not the South-a further possible reason why even right wing Slovenian American publications did not have a highly ideological agenda when reporting on Gone with the Wind, as opposed to publications in states where racial segregation was in full effect, for instance Georgia, where the story takes place. The newspapers Proletarec and Prosveta-the former being openly socialist and the latter with clear socialist sympathies (Pogačar 345-46, 350) - were exceptions; this is in line with left-wing organizations, for instance the Communist Party USA, frequently supporting African Americans' struggles against discrimination during the inter-war period (Ling 118, 125-27; Waldrep 136, 142, 163).

It can thus be concluded that ideology did somewhat influence Slovenian Americans' criticism of Gone with the Wind, while the lack of critical opinions in the majority of publications may be attributed to historical and geographical reasons.

\section{BIBLIOGRAPHY}

Ameriška domovina / American Home. Cleveland, Ohio: J. Debevec, 1919-2008. Asim, Jabari, The $N$ Word: Who Can Say It, Who Shouldn't, and Why. Boston: Houghton Mifflin, 2007.

Ave Maria. Lemont, Illinois: Družba sv. Rafaela za slovenske izseljence v Ameriki, 1909-2016.

Baldick, Chris. The Concise Oxford Dictionary of Literary Terms. Oxford/New York: Oxford University Press, 2001.

Drnovšek, Marjan. "Pojav množičnega izseljevanja Slovencev v Združene države Amerike.” Množično izseljevanje Slovencev v Združene države Amerike. Edited by Marjan Drnovšek and Vilma Brodnik. Ljubljana: Zavod Republike Slovenije za šolstvo, 2002, pp. 7-19.

Dugan, James. "Reconstruction and GWTW." New Masses, vol. 34, no. 6, 1940, pp. 28-30. https://www.marxists.org/history/usa/pubs/new-masses/1940/ v34n06-jan-30-1940-NM.pdf (Accessed 17 January 2021).

Glasilo K.S.K. jednote / Official Organ of the Grand Carniolian Slovenian Catholic Union. Cleveland, Ohio: Kranjsko-slovenska katoliška jednota, 1915-1946. 
Gómez-Galisteo, M. Carmen. The Wind Is Never Gone: Sequels, Parodies and Rewritings of Gone with the Wind. Jefferson, North Carolina/London: McFarland \& Company, Inc., 2011.

Haskell, Molly. Frankly, My Dear: Gone with the Wind Revisited. New Haven/ London: Yale University Press, 2009.

Jeff, Leonard J. “'Gone with the Wind' and Hollywood's Racial Politics.” The Atlantic, December 1999. https:/www.theatlantic.com/magazine/archive/1999/12/ gone-with-the-wind-and-hollywoods-racial-politics/377919/ (Accessed 7 February 2021).

Ling, P. J. “A White Woman's Word: The Scottsboro Case.” Race on Trial: Law and Justice in American History. Edited by Annette Gordon-Reed. Oxford/ New York: Oxford University Press, 2002, pp. 118-38.

Mitchell, Margaret. The Scarlett Letters: The Making of the Film Gone with the Wind. Edited by John Wiley, Jr. Lanham/Boulder/London/New York: Taylor Trade Publishing, 2014.

Mladinski list: mesečnik za slovensko mladino v Ameriki / Juvenile: Monthly Magazine for the Young Slovenes in America. Chicago, Illinois: Slovenska narodna podporna jednota / Slovene National Benefit Society, 1922-2015.

N. N. “Books That Shaped America' Exhibition to Open June 25." Library of Congress, 2012. https://www.loc.gov/item/prn-12-123/ (Accessed 17 January 2021).

Nova doba: uradno glasilo Jugoslovanske katoliske jednote / New Era: Official Organ of the South Slavonic Catholic Union. Cleveland, Ohio: J.S.K. jednota, 1927-1945. Pogačar, Timothy. "Izseljenski tisk v Ameriki v digitalni dobi: slovensko-ameriški časopis Prosveta." Slavistična revija, vol. 65, no. 2, 2017, pp. 343-53. https://srl. si/ojs/srl/article/view/COBISS_ID-64390754 (Accessed 12 January 2021).

Proletarec: glasilo Jugoslovanske socialistične zveze: list za interese delavskega ljudstva. Chicago, Illinois: Jugoslovanska delavska tiskovna družba, 1906-1952.

Prosveta: glasilo Slovenske narodne podporne jednote / Enlightenment: The Publication of the Slovene National Benefit Society. Imperial, Pennsylvania: Slovenska narodna podporna jednota / Slovene National Benefit Society, 1908-.

Ryan, Tim A. Calls and Responses: The American Novel of Slavery since Gone with the Wind. Baton Rouge: Louisiana State University Press, 2008.

Schuessler, Jennifer. "The Long Battle over 'Gone with the Wind'.” The New York Times, 14 June 2020. https:/www.nytimes.com/2020/06/14/movies/gonewith-the-wind-battle.html (Accessed 11 January 2021).

Sova, Dawn B. Banned Books: Literature Suppressed on Social Grounds. New York: Facts on File Inc., 2006.

Stevens, J. D. "The Black Reaction to Gone with the Wind." Journal of Popular Film, vol. 2, no. 4, 1973, pp. 366-71. 
Stewart, Jacqueline."Why we can't turn away from 'Gone with the Wind'. CNN, 25 June 2020. https://edition.cnn.com/2020/06/12/opinions/gone-with-thewind-illuminates-white-supremacy-stewart/index.html(Accessed 12 January 2021). Trupej, Janko. "Recepcija štirih ameriških romanov in njihovih slovenskih prevodov v luči ideologije rasizma." Primerjalna književnost, vol. 38, no. 2, 2015, pp. 213-35. Trupej,Janko. "Ideological Influences on the Reception of Mark Twain among Slovenians across the Atlantic." Acta Neophilologica vol. 52 no. 1-2, 2019, pp. 141-52.

Waldrep, Christopher. The Many Faces of Judge Lynch: Extralegal Violence and Punishment in America. New York/Basingstoke: Palgrave Macmillan, 2002.

Wiley, John, Jr. "Prologue: The Making of a Masterpiece." The Scarlett Letters: The Making of the Film Gone With the Wind. Margaret Mitchell. Edited by John Wiley, Jr. Lanham/Boulder/London/New York: Taylor Trade Publishing, 2014, pp. XIX-XXVIII.

Wiley,John Jr. "Epilogue: Tomorrow Is Another Day." The Scarlett Letters: The Making of the Film Gone With the Wind. Margaret Mitchell. Edited by John Wiley, Jr. Lanham/Boulder/London/New York: Taylor Trade Publishing, 2014, pp. 421-27. Zarja: uradno glasilo Slovenske ženske zveze v Ameriki / The Dawn: Official Organ of the Slovenian Women's Union of America. Chicago, Illinois: Slovenska ženska zveza / Slovenian Women's Union of America, 1929-.

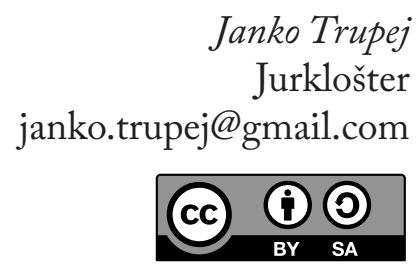

\section{Odzivi na $\boldsymbol{V}$ vrtincu med Slovenci na drugi strani Atlantskega oceana}

Članek obravnava recepcijo romana in filma Gone with the Wind v serijskih publikacijah slovenskih izseljencev oz. zdomcev v Združenih državah Amerike. Analiza je zajemala relevantne članke, ki so bili objavljeni $v$ publikacijah $\mathrm{z}$ različnimi ideološkimi usmeritvami do sredine petdesetih let 20. stoletja, tj. do začetka intenziviranja afroameriškega gibanja za državljanske pravice. Recepcija v slovensko-ameriških publikacijah je primerjana s splošno sodobno recepcijo romana in filma $\mathrm{v} Z \mathrm{ZDA}$. Upoštevajoč zgodovinski kontekst so v članku obravnavani tudi razlogi za razlike v recepciji.

Ključne besede: Margaret Mitchell, $V$ vrtincu, ameriški Slovenci, serijske publikacije, recepcija, ameriška književnost 